\title{
ANALYSIS OF CRITICAL THINKING SKILLS IN REACTION RATE USING GUIDED INQUIRY WITH WEB-ASSISTED COURSES
}

\author{
Ayu Indahyana ${ }^{1}$, Harun Nasrudin ${ }^{2} *$ \\ ${ }^{12}$ Chemistry Departement FMIPA, State University of Surabaya, Ketintang Street \\ Surabaya, Jawa Timur 60231, Indonesia. \\ * Corresponding Author. E-mail: harunnasrudin@unesa.ac.id
}

Received: 15 Januari 2021

Accepted: 30 November 2021 Published: 30 November 2021
doi: 10.29303/cep.v4i3.2399

\begin{abstract}
This research aims to describe the result of the analysis students` critical thinking skills through the implementation of guided inquiry learning models with web-assisted courses in reaction rate. The subject is students` XI MIPA 2 SMAN 1 Taman. The type of this research is pre-experimental design with one group pretest-posttest design. This research uses observation, test and questionnaire methods. The instruments used are a sheet of the critical thinking skills test, observation sheet of learning model implementation, activity observation sheet, and student response questionnaire sheets. Quantitative methods with SPSS 23 to analyze this research data. The result of this research showed that (1)The percentage of learning model implementation at the first and second meetings are 98,06\% (very good) and $99,07 \%$ (very good). (2)The relevant activities of student's at the first and second meetings are $98,47 \%$ and $97,84 \%$. (3) Students' critical thinking skill is successfully trained with the average gain score on the interpretation indicator is 0.90 (high), inference indicator is 0,93 (high), analysis indicator is 0,90 (high) and explanation indicator is 0,89 (high). (4)The positive response of students is $91.18 \%$. The results showed that the guided inquiry learning model with web-assisted courses in reaction rate material could improving students' critical thinking skills.
\end{abstract}

Keywords: Critical Thinking Skills, Reaction Rate, Guided Inquiry, Web-Assisted Courses.

\section{Analisis Keterampilan Berpikir Kritis Pada Materi Laju Reaksi Menggunakan Inkuiri Terbimbing Berbantuan Web Course}

\begin{abstract}
Abstrak
Penelitian ini bertujuan untuk mendeskripsikan hasil analisis keterampilan berpikir kritis peserta didik melalui penerapan model pembelajaran inkuiri terbimbing berbantuan web course pada materi laju reaksi. Sasaran penelitian yaitu peserta didik XI MIPA 2 SMAN 1 Taman. Jenis penelitian ini adalah pre-experimental design dengan rancangan one group pretest posttest design. Penelitian ini menggunakan metode observasi, tes, dan angket. Instrument yang digunakan yaitu lembar soal tes keterampilan berpikir kritis, lembar pengamatan keterlaksanaan model pembelajaran, lembar pengamatan aktivitas peserta didik, dan lembar angket respon peserta didik. Data dianalisis menggunakan teknik kuantitatif berbantuan SPSS 23. Hasil penelitian menunjukkan bahwa (1)Persentase keterlaksanaan model pembelajaran inkuiri terbimbing berbantuan web course pada pertemuan pertama sebesar 98,06\% (sangat baik) dan pertemuan kedua sebesar 99,07\% (sangat baik). (2)Aktivitas relevan peserta didik pada pertemuan pertama sebesar 98,47\% dan pertemuan kedua sebesar 97,84\% (3)Keterampilan berpikir kritis peserta didik berdasarkan hasil pretest dan posttest mendapatkan rata-rata gain score pada indikator interpretasi sebesar 0,90 (tinggi), indikator inferensi sebesar 0,93 (tinggi), indikator analisis sebesar 0,90 (tinggi), dan indikator eksplanasi sebesar 0,89 (tinggi). (4)Respon positif peserta didik terhadap proses pembelajaran sebesar 91,18\%. Berdasarkan hasil penelitian tersebut dapat disimpulkan bahwa model pembelajaran inkuiri terbimbing berbantuan web course pada materi laju reaksi berhasil meningkatkan keterampilan berpikir kritis peserta didik.
\end{abstract}

Kata Kunci: Keterampilan Berpikir Kritis, Laju Reaksi. Inkuiri Terbimbing, Berbantuan Web Course. 
avoided in the $21^{\text {st }}$ century, this requires educators to present collaborative learning content to prepare competent students (Prayogi \& Estetika, 2019). The $21^{\text {st }}$ century demands a country's human resources to master various forms of skills known as 4C (creative, critical thinking, communicative, dan collaborative) (Direktorat Pembinaan SMA, 2017). The implementation of 2013 curriculum is the government's effort to face the challenges of $21^{\text {st }}$ century, which was developed by improving nine mindsets, the one is critical learning pattern (Kemendikbud, 2018a).

In the current education system, implementing the 2013 curriculum is that students are allowed to solve problems around them through the application of information learned both in school and in everyday life by emphasizing cognitive, attitude, and skill aspects (Munandar \& Amiruddin, 2020). It requires the sensitivity of teachers to make innovations in education to create quality human resources.

Natural science is a part of education that has an important role in realizing quality education. Chemistry is a natural science branch that is a compulsory subject in the learning curriculum in high schools (Kemendikbud, 2018 b). Chemistry contains abstract concepts, so it becomes difficult to teach and understand students (Hidayat, 2017). Chemistry learning includes material on reaction rates. According to Chang \& Overby (2019), the reaction rate is defined as the rate which reactants decrease or the rate at products change. In the reaction rate, there are sub matter factors that affect reaction rate which in cognitive competence refers to $K D 3.4$ and skill competence refers to $K D 4.5$ (Kepala Badan Penelitian dan Pengembangan dan Perbukuan, 2020).

Based on the pre-research results on Tuesday, September $1^{\text {st }} 2020$ at SMAN 1 Taman, it was stated that $57.70 \%$ students experienced difficulties in chemistry lessons because of the many theories to be studied, calculations, and lots of memorization. One chemical material that is difficult to learn is reaction rate with $57.70 \%$ students considering this material. In addition, a total of $76.90 \%$ of students want to study reaction rates using the experiment. Previous research also states that sub matter factors that affect reaction rate are prone to misconceptions because of its abstract character which causes students to have difficulty understanding concepts, so it's necessary to prove experimental activities to improve students' understanding (Titari \& Nasrudin, 2017).
According to the reaction rate material's characteristics to prove the concept, investigation through experimental activities is done to understand the material reaction rate conceptually and procedurally easily. Inquirybased experimental activities students carry out investigations, namely interpreting, analyzing, concluding and explaining (Auliya et al., 2020). So from there, students are required to have critical thinking skills.

According to Facione (2015), critical thinking skills consist of several indicators, namely interpretation, inference, analysis, explanation, evaluation, and self-regulation. Critical thinking is the main goal of learning in accordance with Permendikbud number 20 the year 2016, where students are expected to use reasoning methods in solving problems in various sciences and everyday life so that they can develop understanding and concepts that will be obtained for longer stored in memory because students are actively involved in learning to find concepts independently which involves testing, connecting and evaluating all aspects of a problem (Kemendikbud, 2016a).

Students' critical thinking skills are still low, based on the pre-research test results in class XII MIPA-2 at SMAN 1 Taman on Tuesday, September $1^{\text {st }} 2020$. The results from 20 students showed that the average score was low, the interpretation indicator is 22.50, analysis indicator is 57.00, inference indicator is 8.33 and explanation indicator is 29.00 . From these results, the critical thinking skills of students need to be improved. It is necessary to handle students' critical thinking skills further.

The guided inquiry learning model is one of the learning models that can train critical thinking skills through six syntaxes, namely focusing the attention of students and explaining an inquiry process, presenting an inquiry problem or phenomenon, encouraging students to formulate hypotheses to explain problems or phenomena, encourage students to collect data to test hypotheses, formulate explanations and conclusions, reflect on problem situations and thought processes (Arends, 2012).

Previous research supports that the inquiry learning model on electrolyte and non-electrolyte solution material got very good criteria with the percentage of the first meeting are $96.43 \%$ and the second meeting is $97.62 \%$, the relevant activity is very good (Firdausichuuriyah \& Nasrudin, 2017). Another research stated that the implementation of guided inquiry learning in 
reaction rate material was very effective and able to practice critical thinking skills with classical completeness of $92.02 \%$ and increase gain score in the high category (Ulya \& Nasrudin, 2019). Other similar studies also apply the guided inquiry learning model to train critical thinking skills in reaction rate material obtained by a test score with the average gain score is 0.90 on the interpretation indicator, 0.73 on the analysis indicator, 0.76 on the evaluation indicator and 0.88 on the inference indicator which is included high category (Cahyani \& Azizah, 2019).

Referring to the excellent results of previous research, the guided inquiry learning model is very appropriate for learning. Its will be carried out with web-assisted courses due to the current condition of Coronavirus Disease (COVID-19) pandemic. To maintain the health of students, teachers, school principals and all school members, Ministry of Education and Culture makes a policy that the implementation of education in the emergency period of the spread COVID-19 is done through online or distance learning (Kemendikbud, 2020).

Web-assisted courses use the internet for educational purposes, where students and educators are completely separate. All teaching materials, discussions, consultations, exercises, exams, and other learning activities are fully conveyed via the internet (Plessis, 2017). Learning using web-assisted courses has the advantages of being easy to access, easy to use, increase motivation, and form a culture of independent education (Kefalis \& Drigas, 2019).

In this research, website-based applications used are Google Classroom and WhatsApp Group for virtual classes, Google Meet to interact directly, and YouTube for experimental video presenter. The use of YouTube videos for learning resource can increase student interest, participation, and insight. According to cognitive theory, videos effectively construct knowledge construction and memory development (Buzzetto, 2017).

It is supported by the results of a preresearch questionnaire at SMAN 1 Taman which states that $100 \%$ students often use the internet for learning resource and $73.10 \%$ want the internet to be used in modern chemistry learning. $76.90 \%$ of students believe that the level understanding of chemistry subject matter will increase if the internet is used for learning resource. Reinforced by the results of previous research concludes that guided inquiry learning using web media on the reaction rate material is effective because it can improve student learning outcomes (Matondang, 2017). Other previous research also stated that inquiry models assisted by web-enhanced course to practice critical thinking skills could be effective with more relevant activities. Students' average score has increased in all indicators of critical thinking skills and increase of students' learning outcomes of students (Fadilah et al., 2019).

Based on the facts described above, the authors hope that the guided inquiry learning model with web-assisted courses in sub matter factors that affect reaction rate will do very well so can improve students' critical thinking skills, a lot of relevant activities, and get a positive response from students of SMAN 1 Taman.

\section{METHOD}

This research type is pre-experimental, carried out only in one class XI MIPA 2 without any comparison class at SMAN 1 Taman. This research was conducted in the odd semester of the $2020 / 2021$ school year with 2 meetings, on $7^{\text {th }}$ and $9^{\text {th }}$ October 2020 with the one-group pretestposttest design research.

Information :

$$
\mathrm{O}_{1}-\mathrm{X}-\mathrm{O}_{2}
$$

$\mathrm{O}_{1}$ : Initial test (pretest).

$\mathrm{X}$ : The treatment of guided inquiry learning model with web-assisted courses.

$\mathrm{O}_{2}$ : Final test (posttest).

The learning tools used in this research are syllabus, lesson plan, and student worksheet. The research instrument used is observation sheet for implementing learning, test sheet for critical thinking skills, student's activity observation sheet, and student response questionnaire.

This research uses observational methods to observe the learning implementation and activities of students. Test method to measure students' critical thinking skills was given twice (pretest and posttest). And the questionnaire method is to determine student responses from the learning that have been carried out.

Research tools and instruments before being used to retrieve data begins with validation. The following formula can determine the validation assessment.

$$
\% \text { Validation }=\frac{\sum \text { Overall score }}{\sum \text { Criteria score }} \times 100 \%
$$

Percentage of validity the learning tools and research instruments obtained is converted to the criteria in Table 1. 
Table 1. Criteria for Percentage of Validity

\begin{tabular}{cc}
\hline Percentage & Criteria \\
\hline $0 \%-20 \%$ & Very less valid \\
$21 \%-40 \%$ & Less valid \\
$41 \%-60 \%$ & Enough valid \\
$61 \%-80 \%$ & Valid \\
$81 \%-100 \%$ & Very valid \\
\hline
\end{tabular}

Source: Riduwan (2015).

The calculation percentage of learning model implementation can use a formula.

$\%$ Implementation $=\frac{\text { Score obtain }}{\text { Maximum score }} \times 100 \%$

Observer then averaged using the following formula.

$$
\% \text { Average }=\frac{\% \text { implementation }}{\text { number of observer }}
$$

The results obtained are described as the criteria for each syntax according to Table 2 .

Table 2. Implementation Criteria

\begin{tabular}{cc}
\hline Percentage & Criteria \\
\hline $0 \%-20 \%$ & Very less \\
$21 \%-40 \%$ & Less \\
$41 \%-60 \%$ & Enough \\
$61 \%-80 \%$ & Good \\
$81 \%-100 \%$ & Very good \\
\hline
\end{tabular}

Source: Riduwan (2015)

Analysis of student activity data is calculated based on the number of frequencies that occur when teaching and learning activities occur with the following formula.

$\%$ Student Activity $=\frac{\sum \text { Frequency of activity that appears }}{\sum \text { Frequency of overall activity }} \times 100 \%$

Observer then averaged using the following formula.

$$
\% \text { Average }=\frac{\% \text { Activities }}{\text { Number of observer }}
$$

An activity is declared good if the percentage of relevant activities is greater than the percentage of irrelevant activities.

Critical thinking skills are analyzed based on the pretest and posttest scores on each indicator with its following assessment formula.

Score of Critical Thinking $=\frac{\text { Score obtain }}{\text { Maximum score }} \times 100$

The value data from pretest and posttest for each indicator critical thinking skills were carried out by descriptive analysis using SPSS 23, then the normality test was carried out using the Kolmogorov-Smirnov method to determine whether the value data of each indicator was normally distributed. The following is the basis for making the decision:

a. If the significance value $(\mathrm{sig})>0.05$, then the research data for critical thinking skills is normally distributed.

b. If the significance value (sig) $<0.05$, then the research data for critical thinking skills is not normally distributed.

The difference in the average pretest and posttest scores on each indicator was analyzed using paired sample t-test using SPSS 23. The following is the basis for making the decision:

a. If the significance value (2-tailed) $<0.05$, then Ho is rejected and $\mathrm{Ha}$ is accepted.

b. If the significance value (2-tailed) $>0.05$; then Ho is accepted and Ha is rejected.

With the following hypothesis:

$\mathrm{H}_{\mathrm{o}}=$ There is no average difference between pretest and posttest results on critical thinking skill indicators.

$\mathrm{Ha}=$ There is an average difference between pretest and posttest results on critical thinking skill indicators.

The gain score is then calculated to determine how much increase between pretest and posttest scores on each indicator with the following formula.

$$
<\mathrm{g}>=\frac{\text { Score pretest }- \text { Score posttest }}{\text { Score maximum }- \text { Score pretest }}
$$

The gain score obtained is adjusted to the criteria in Table 3.

Table 3. Gain Score Criteria

\begin{tabular}{cc}
\hline$(<\mathrm{g}>)$ score & Criteria \\
\hline$\langle\mathrm{g}>\geq 0,7$ & High \\
$0,7>\langle\mathrm{g}>\geq 0,3$ & Average \\
$\langle\mathrm{g}><0,3$ & Low
\end{tabular}

Source: Riduwan (2015)

Student response data were analyzed quantitatively by describing the percentage in each question. The calculation can use a formula. $\%$ Response of students $=\frac{\sum \text { Positive Response }}{\Sigma \text { Responden }} \times 100 \%$ The results percentage of student responses obtained converted to same criteria in table 2 .

\section{RESULT AND DISCUSSION}

Before use to collect data, learning tools and research instruments need to be reviewed and validated to test their validity when implementation in schools. One lecturer reviews, while two lecturers carry out the validation. 
Obtained the percentage of validity results on the syllabus is $87.50 \%$ (very valid), the lesson plan is $81.25 \%$ (very valid), the worksheet is $80.47 \%$ (valid). The results of validation research instrument showed that the percentage of validity on the observation sheet of learning implementation is $80.00 \%$ (valid), observation sheet on student activity is $75.00 \%$ (valid), critical thinking skill test sheet is $84.38 \%$ (very valid), the rubric of critical thinking skills test assessment is $81.25 \%$ (very valid) and student response questionnaire sheet is $75.00 \%$ (valid). These results indicate that the learning tools and research instruments are valid for collecting research data.

\section{Implementation of Learning Model}

Three observers conducted an assessment of the feasibility of learning model using the implementation observation sheet for two meetings. Observation aims to determine the implementation of syntax in guided inquiry learning model with web-assisted courses. The first meeting on Wednesday, October $7^{\text {th }} 2020$ discussed four factors that affect reaction rate by observing the experimental video on YouTube. The second meeting on Friday, October $9^{\text {th }} 2020$, to prove the effect of temperature and surface area on the reaction rate by conducting experiments using tools and materials in everyday life at each student's homes. At two meetings, the learning activities took advantage of web-based applications, namely Google Classroom and WhatsApp Group for virtual classes, Google Meet for face-to-face learning between teachers and students, then YouTube for experimental video presenter.

The results of implementation obtained at two meetings are shown in Figure 1.

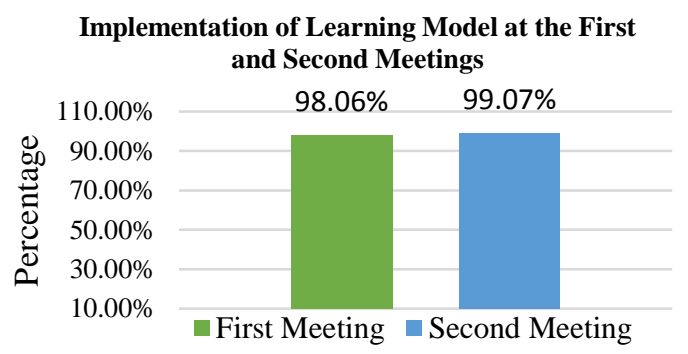

Figure 1. Percentage of Implementation Learning Model at the First and Second Meetings

Figure 1 shows the average percentage of learning implementation at the first meeting is $98.06 \%$ and the second meeting is $99.07 \%$ which indicates that the application of Inquiry learning model with web-assisted courses at two meetings can be carried out very well. Details of the results of implementing learning for each phase are shown in Figure 2.

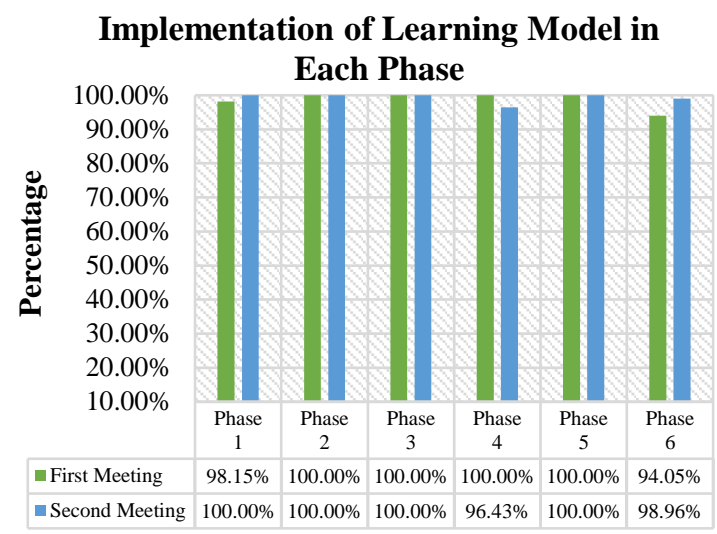

Figure 2. Percentage of Implementation Guided Inquiry Learning Model with WebAssisted Courses in Each Phase

The following is a discussion of each phase.

Phase 1 focuses on the students' attention and explains the inquiry process (Arends, 2012). In this phase, learning is done through Google Meet. The activities are teacher opening lessons, making perceptions, providing motivation, and giving students' perception by linking the material with students' initial knowledge of collision theory. The teacher motivates by a picture of one phenomenon the reaction rate factors, then teacher conveys learning objectives and material to be studied. The percentage of implementation phase 1 at the first meeting is $98.15 \%$ and the second meeting is $100 \%$, with each of them getting very good criteria.

Phase 2 presents the problem of inquiry (Arends, 2012). In this phase, learning is done through Google Meet assisted by Google Classroom. The activity carried out is the teacher sends a worksheet file, and students are asked to download. The teacher explains how to use the worksheet and guides students to understand experimental phenomena. The percentage of implementation of phase 2 at the first meeting is $100 \%$ and the second meeting is $100 \%$, with very good criteria.

Phase 3 asks students formulate hypotheses to explain the problem (Arends, 2012). In this phase, learning is done through Google Meet. The activity carried out is teacher guides students to formulate problems, including interpretive, critical thinking skill (Facione, 2015). Then students are asked to make hypotheses based on the phenomena that have been observed, including inference critical thinking skill (Facione, 2015). The percentage of implementation of phase 3 at the first meeting is 
$100 \%$ and the second meeting is $100 \%$, with each of them getting very good criteria.

Phase 4 encourages students to collect data to test hypotheses (Arends, 2012). Learning in this phase is done through Google Meet, Google Classroom, WhatsApp Group, and YouTube. Students observed a video experiment of four factors that affect reaction rate via YouTube at the first meeting. Whereas at the second meeting students conducted experiments directly at their respective homes using tools and materials in everyday life to prove the effect of temperature (odd absences) and surface area on reaction rate (even absences). As long as students carry out experimental activities at home, the teacher also monitors their progress through Google Classroom and WhatsApp Group. To ensure that all students have conducted an experiment, the teacher asks students to make a video recording and send it to Google Classroom. Indicator of interpretation critical thinking skill are trained in this phase. The percentage of implementation phase 4 at the first meeting is $100 \%$ and the second meeting is $96.43 \%$, with each getting very good criteria.

Phase 5 formulates an explanation and/or conclusion (Arends, 2012). In this phase, learning is done through Google Meet. The activities carried out were teacher guiding students to analyze data by answering questions on the worksheet and making conclusions. Indicators of critical thinking skills trained is analysis and inference. The percentage of implementation phase 5 at the first meeting is $100 \%$ and the second meeting is $100 \%$, with each of them getting very good criteria.

Phase 6 reflects on the problems and thought processes used during the investigation (Arends, 2012). In this phase learning through Google Classroom as a place to collect assignments and WhatsApp Group as a place for discussion, this is due to school policies that only allow 30 minutes of face-to-face learning using Google Meet. The activities carried out were four student representatives presenting the results of their worksheets. Each student will present one reaction rate factor, and the other can respond. Teacher comments on and provides reinforcement related to the discussion results and give rewards to students who have participated. Closing activity was continued by concluding the lesson, giving assignments for the next meeting, praying, and closing greetings. Indicator of explanation critical thinking skill are trained in this phase to state the results of reasoning and present arguments (Facione, 2015). The percentage of implementation phase 6 at the first meeting is $94.05 \%$ and the second meeting is $98.96 \%$, with each of them getting very good criteria.

Based on the description above, the implementation of guided inquiry learning syntax with web-assisted courses for two meetings has been carried out very well. It indicates that the critical thinking skills of students can be trained. The guided inquiry learning model is oriented towards independent concept discovery activities through investigation, so this learning model application can guide students in developing maximum potential of the mind with the thought process to find solutions from experimental problems (Febriani \& Ismono, 2020).

The most dominant phase can help students improve their critical thinking skills, in phase 4 at the second meeting, because students carry out activities to test a hypothesis by collecting data. When collecting experimental data directly, students can test the problem formulation, hypotheses, variables, experimental procedures, analyze data and conclude the experiment results. It is according to relevant previous research that states phase 4 from guided inquiry is the dominant phase to help students improve their critical thinking skills (Mukmainah \& Yonata, 2020).

\section{Students Activities}

This observation aims to see all activities of students in the learning process using guided inquiry model with web-assisted courses. Observations were made by three observers every two minutes during the learning process. The activities of students during two meetings are shown in Figure 3.

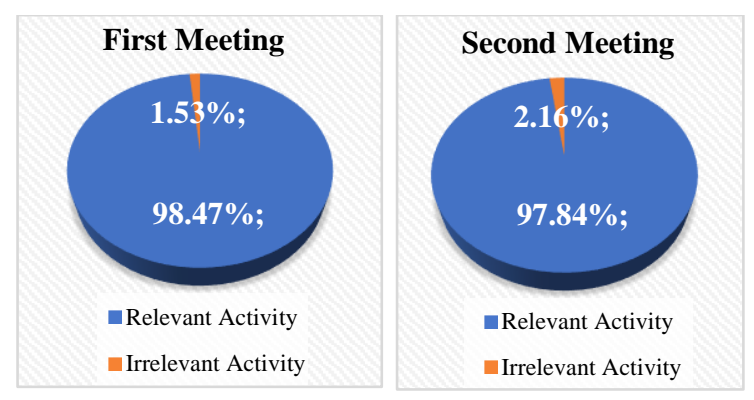

Figure 3. The Graph of Pie Relevant and Irrelevant Activity

In general, figure 4 shows that students do more relevant activities than irrelevant activities. In the first meeting, there are more relevant activities than in the second meeting. Details of student activities are listed in Table 4. 
Table 4. Percentage of Students' Activities

\begin{tabular}{|c|c|c|}
\hline $\begin{array}{c}\text { Student Activities } \\
\text { Through Virtual Class }\end{array}$ & $\begin{array}{c}\text { First } \\
\text { Meeting }\end{array}$ & $\begin{array}{c}\text { Second } \\
\text { Meeting }\end{array}$ \\
\hline 1. Answer the question & $14,50 \%$ & $15,11 \%$ \\
\hline 2. Ask the teacher & $5,43 \%$ & $6,47 \%$ \\
\hline $\begin{array}{l}\text { 3. Formulate the problem } \\
\text { (Interpretation) }\end{array}$ & $3,05 \%$ & $2,88 \%$ \\
\hline 4. Proposing a hypothesis (Inference) & $3,05 \%$ & $2,88 \%$ \\
\hline $\begin{array}{l}\text { 5. Determine the experimental } \\
\text { variable (Interpretation) }\end{array}$ & $3,05 \%$ & $2,88 \%$ \\
\hline $\begin{array}{l}\text { 6. Observing the experiment video } \\
\text { by sending photo evidence while } \\
\text { observing (First meeting) } \\
\text { Conducting experiments at } \\
\text { home, proven by sending a video } \\
\text { recording of the activity } \\
\text { (Second meeting) }\end{array}$ & $19,08 \%$ & $18,71 \%$ \\
\hline $\begin{array}{l}\text { 7. Arrange experimental data into } \\
\text { observational data tables } \\
\text { (Analysis) }\end{array}$ & $19,85 \%$ & $17,99 \%$ \\
\hline $\begin{array}{l}\text { 8. Answering analysis questions } \\
\text { contained in the worksheet } \\
\text { (Analysis) }\end{array}$ & $18,32 \%$ & $17,99 \%$ \\
\hline 9. Making conclusions (Inference) & $3,05 \%$ & $2,88 \%$ \\
\hline $\begin{array}{l}\text { 10. Presenting the results of } \\
\text { experiment (explanation) }\end{array}$ & $3,05 \%$ & $2,88 \%$ \\
\hline $\begin{array}{l}\text { 11. Responding to a presentation being } \\
\text { made by a friend (Eksplanasi) }\end{array}$ & $6,11 \%$ & $7,19 \%$ \\
\hline 12. Irrelevant activity & $1,53 \%$ & $2,16 \%$ \\
\hline
\end{tabular}

Based on table 4 , it can be seen that there are differences in activities of students at the first meeting and second meeting. The percentage is obtained from the average frequency of each student's activity observed by observers in virtual classes, namely Google Meet, Google Classroom, and WhatsApp Groups. Irrelevant activities such as writing questions, answering questions from the teacher, or sending something that is not suitable and is not needed in online learning activities affects reaction rate material.

At the first meeting learned about four factors that affect reaction rate by watching experimental video on YouTube. The most student activity with $19.85 \%$ is arrange experimental data into observational data tables at the worksheet and then sending them via Google Classroom. This activity trains critical thinking skills on analysis indicator. There were $1.53 \%$ irrelevant activities because two students sent writing outside the subject matter.

At the second meeting, students proved the effect of temperature and surface area in rate reaction by conducting experimental activities using tools and materials in daily life at their respective homes, this activities received the highest percentage yield with $18.71 \%$. It is in accordance with the principles of learning chemistry based on the 2013 curriculum, which is expected to encourage students to become active learners and become learning centres (Kemendikbud, 2016b). A number of irrelevant activities are $2.16 \%$ because three students answered questions outside the material and sent experimental videos that couldn't be played.

All activities carried out by students can happen very well, this can support the implementation of learning so that students' critical thinking skills can improve. According to the previous researcher's statement, success improving critical thinking skills is due to higher relevant student activity so that the learning process with guided inquiry is carried out very well (Firdausichuuriyah \& Nasrudin, 2017).

\section{Critical Thinking Skills}

Before getting the lesson, students are given a pretest sheet question about factors that affect reaction rate by containing indicators of critical thinking skills to identify students' initial skills (Febriani \& Ismono, 2020).

There are six main critical thinking indicators, namely, interpretation, inference, analysis, explanation, evaluation, and selfregulation (Facione, 2015). In this study only took four indicators, namely interpretation, inference, analysis and explanation. The process of practising critical thinking skills by implementation a guided inquiry learning model using worksheets with learning activities according to the indicators of critical thinking skills being trained. At the end of learning, students are given a posttest sheet.

Data on the pretest and posttest scores for each indicator critical thinking skills were analyzed descriptively using SPSS 23. And normality tests with Kolmogorov-Smirnov method to determine whether the value data was normally distributed. The paired sample t-test was then conducted to determine the average difference between the pretest and posttest scores of critical thinking skills. To find out how big the difference is, the gain score is calculated.

The following is a discussion of each indicator of critical thinking skills.

Interpretation indicators is the ability to understand, explain, and give meaning to data, events or phenomena, findings or information (Facione, 2015). Activities carried out by students are formulating problems, determining experimental variables, and making tables of observation results. Data of pretest and posttest values on the interpretation indicator were carried out by descriptive analysis, normality test, and paired sample t-test using SPSS 23. The 
descriptive analysis results showed that the lowest pretest score is 25.00 and the highest is 75.00 , with an average is 50.36 . While the lowest posttest score is 84.38 and highest is 100.00 , with an average is 94.83 . The normality test on interpretation indicator with the KolmogorovSmirnov method get a significance value of 0.188 $>0.05$, indicating that the research data is normally distributed. The result of paired sample $\mathrm{t}$-test on interpretation indicator obtained Sig value ( 2 -tailed) is $0.000<0.05$, then Ho was rejected and Ha accepted. It means that there is an average difference between pretest and posttest results on the interpretation indicator. To find out how big the difference is, gain score is calculated, the result in Table 5.

Table 5. Results of the Gain Score Calculation on the Interpretation Indicator

\begin{tabular}{|c|c|c|c|c|c|}
\hline No. & Name & Pretest & Posttest & ain Sc & ategory \\
\hline 1. & S1 & 65,63 & 93,75 & 0,82 & High \\
\hline 2. & $\mathrm{~S} 2$ & 25,00 & 96,88 & 0,96 & High \\
\hline 3. & S3 & 68,75 & 96,88 & 0,90 & High \\
\hline 4. & S4 & 65,63 & 100,00 & 1,00 & High \\
\hline 5. & S5 & 68,75 & 100,00 & 1,00 & High \\
\hline 6. & S6 & 75,00 & 96,88 & 0,88 & High \\
\hline 7. & S7 & 59,38 & 96,88 & 0,92 & High \\
\hline 8. & S8 & 25,00 & 96,88 & 0,96 & High \\
\hline 9. & S9 & 34,38 & 93,75 & 0,90 & High \\
\hline 10. & S10 & 46,88 & 84,38 & 0,71 & High \\
\hline 11. & S11 & 37,50 & 96,88 & 0,95 & High \\
\hline 12. & $\mathrm{~S} 12$ & 59,38 & 93,75 & 0,85 & High \\
\hline 13. & S13 & 28,13 & 93,75 & 0,91 & High \\
\hline 14. & S14 & 25,00 & 93,75 & 0,92 & High \\
\hline 15. & S15 & 40,63 & 87,50 & 0,79 & High \\
\hline 16. & S16 & 59,38 & 96,88 & 0,92 & High \\
\hline 17. & S17 & 28,13 & 84,38 & 0,78 & High \\
\hline 18. & S18 & 56,25 & 87,50 & 0,71 & High \\
\hline 19. & S19 & 65,63 & 96,88 & 0,91 & High \\
\hline 20. & S20 & 59,38 & 100,00 & 1,00 & High \\
\hline 21. & S21 & 62,50 & 93,75 & 0,83 & High \\
\hline 22. & $\mathrm{~S} 22$ & 62,50 & 96,88 & 0,92 & High \\
\hline 23. & $\mathrm{~S} 23$ & 34,38 & 90,63 & 0,86 & High \\
\hline 24. & $\mathrm{~S} 24$ & 37,50 & 100,00 & 1,00 & High \\
\hline 25. & $\mathrm{~S} 25$ & 56,25 & 100,00 & 1,00 & High \\
\hline 26. & S26 & 62,50 & 96,88 & 0,92 & High \\
\hline
\end{tabular}

Information: $\mathrm{S}=$ Student

Based on table 7 , it can be seen that the interpretation indicator have been successfully trained with all students getting the high category and the average gain score is 0.90 .

Inference indicator is the ability to identify and obtain elements needed to make a reasonable conclusion. One form of inference is selecting relevant information and then conclude (Facione, 2015). Activities carried out by students are formulating hypotheses and making conclusions from the experimental results. Data of pre-test and post-test values on the inference indicator were carried out by descriptive analysis, normality test, and paired sample t-test using SPSS 23 . The descriptive analysis results showed that the lowest pretest score is 25.00 and the highest is 62.50 , with an average is 43.63 . While the lowest posttest score is 87.50 and highest is 100.00 , with an average is 96.16 . The result of normality test on inference indicator with the Kolmogorov-Smirnov method get a significance value of $0.128>0.05$, indicating that the research data is normally distributed. The result of paired sampe t-test on inference indicator obtained $\mathrm{Sig}$ value (2-tailed) is $0.000<0.05$, then Ho was rejected and $\mathrm{Ha}$ accepted. It means that there is an average difference between pretest and posttest results on the inference indicator. To find out how big the difference is, gain score is calculated, the result in Table 6 .

Tabel 6. Results of the Gain Score Calculation on the Inference Indicator 


\begin{tabular}{cccccc}
\hline No. & Name & Pretest & Posttest & Gain Score Category \\
\hline 1. & S1 & 59,38 & 93,75 & 0,85 & High \\
2. & S2 & 40,63 & 90,63 & 0,84 & High \\
3. & S3 & 56,25 & 93,75 & 0,86 & High \\
4. & S4 & 62,50 & 96,88 & 0,92 & High \\
5. & S5 & 62,50 & 90,63 & 0,75 & High \\
6. & S6 & 59,38 & 100,00 & 1,00 & High \\
7. & S7 & 50,00 & 100,00 & 1,00 & High \\
8. & S8 & 34,38 & 96,88 & 0,95 & High \\
9. & S9 & 37,50 & 93,75 & 0,90 & High \\
10. & S10 & 31,25 & 96,88 & 0,95 & High \\
11. & S11 & 37,50 & 96,88 & 0,95 & High \\
12. & S12 & 43,75 & 93,75 & 0,89 & High \\
13. & S13 & 28,13 & 93,75 & 0,91 & High \\
14. & S14 & 28,13 & 100,00 & 1,00 & High \\
15. & S15 & 40,63 & 90,63 & 0,84 & High \\
16. & S16 & 43,75 & 87,50 & 0,78 & High \\
17. & S17 & 25,00 & 90,63 & 0,88 & High \\
18. & S18 & 37,50 & 96,88 & 0,95 & High \\
19. & S19 & 43,75 & 100,00 & 1,00 & High \\
20. & S20 & 34,38 & 100,00 & 1,00 & High \\
21. & S21 & 43,75 & 96,88 & 0,94 & High \\
22. & S22 & 43,75 & 100,00 & 1,00 & High \\
23. & S23 & 59,38 & 100,00 & 1,00 & High \\
24. & S24 & 43,75 & 100,00 & 1,00 & High \\
25. & S25 & 43,75 & 100,00 & 1,00 & High \\
26. & S26 & 43,75 & 100,00 & 1,00 & High \\
\hline
\end{tabular}

Information: $\mathrm{S}=$ Student

Based on table 10, it can be seen that the inference indicator have been successfully trained with all students getting the high category and the average gain score is 0.93 .

Analysis indicator is the ability of testing data to identify the relationship of some information used to express thoughts or opinions, it can be done from finding problems in designing problem-solving plans (Facione, 2015). Activities carried out by students are analyzing experimental data by answering questions on the worksheet. Data of pretest and posttest values have been carried out by descriptive analysis, normality test, and paired sample t-test using SPSS 23. The descriptive analysis results showed that the lowest pretest score is 18.75 and highest is 68.75 , with an average is 34.13 . While the lowest posttest score is 81.25 and highest is 100.00 , with an average is 93.75 . The result of normality test on analysis indicator with the Kolmogorov-Smirnov method get a significance value of $0.331>0.05$, indicating that the research data is normally distributed. The result of paired sampe t-test on analysis indicator obtained $\mathrm{Sig}$ value (2-tailed) is $0.000<0.05$, then Ho was rejected and Ha accepted. It means that there is an average difference between pretest and posttest results in the analysis indicator. To find out how big the difference is, gain score is calculated, the result shown in Table 7.

Tabel 7. Results of the Gain Score Calculation on the Analysis Indicator

\begin{tabular}{cccccc}
\hline No. & Name & Pretest & Posttest & Gain Score & Category \\
\hline 1. & S1 & 37,50 & 100,00 & 1,00 & High \\
2. & S2 & 37,50 & 87,50 & 0,80 & High \\
3. & S3 & 43,75 & 87,50 & 0,78 & High \\
4. & S4 & 50,00 & 87,50 & 0,75 & High \\
5. & S5 & 50,00 & 93,75 & 0,88 & High \\
6. & S6 & 43,75 & 87,50 & 0,78 & High \\
7. & S7 & 43,75 & 93,75 & 0,89 & High \\
8. & S8 & 31,25 & 100,00 & 1,00 & High \\
9. & S9 & 25,00 & 93,75 & 0,92 & High \\
10. & S10 & 37,50 & 87,50 & 0,80 & High \\
11. & S11 & 25,00 & 93,75 & 0,92 & High \\
12. & S12 & 37,50 & 100,00 & 1,00 & High \\
13. & S13 & 25,00 & 100,00 & 1,00 & High \\
14. & S14 & 25,00 & 93,75 & 0,92 & High \\
15. & S15 & 68,75 & 100,00 & 1,00 & High \\
16. & S16 & 25,00 & 93,75 & 0,92 & High \\
17. & S17 & 31,25 & 81,25 & 0,73 & High \\
18. & S18 & 25,00 & 100,00 & 1,00 & High \\
19. & S19 & 31,25 & 93,75 & 0,91 & High \\
20. & S20 & 25,00 & 93,75 & 0,92 & High \\
21. & S21 & 18,75 & 100,00 & 1,00 & High \\
22. & S22 & 31,25 & 100,00 & 1,00 & High \\
23. & S23 & 25,00 & 87,50 & 0,83 & High \\
24. & S24 & 25,00 & 100,00 & 1,00 & High \\
25. & S25 & 31,25 & 93,75 & 0,91 & High \\
26. & S26 & 37,50 & 87,50 & 0,80 & High \\
\hline
\end{tabular}

Information: $\mathrm{S}=$ Student

Based on table 7, it can be seen that the analysis indicator have been successfully trained with all students getting the high category and the average gain score is 0.90 .

Explanation indicator can explain or state results of thoughts based on evidence, methodology, and context (Facione, 2015). Activities carried out by students are answering questions about explaining the relationship of factors that affect reaction rate using collision theory and presenting the results of the experiment. Data of pretest and posttest values on the explanation indicator were carried out by descriptive analysis, normality test, and paired sample t-test using SPSS 23. The descriptive analysis results showed that the lowest pretest score is 25.00 and the highest is 75.00 , with an average is 45.43 . While the lowest posttest score is 81.25 and highest is 100.00 , with an average is 93.51. The result of normality test on explanation indicator with the Kolmogorov-Smirnov method get a significance value of $0.551>0.05$, indicating that the research data is normally 
distributed. The result of paired sample t-test on explanation indicator obtained Sig value (2tailed) is $0.000<0.05$, then Ho was rejected and $\mathrm{Ha}$ accepted. It means that there is an average difference between the pretest and posttest results on the explanation indicator. To find out how big the difference is, gain score is calculated, the result of gain score shown in Table 8 .

Table 8. Results of the Gain Score Calculation on the Explanation Indicator

\begin{tabular}{|c|c|c|c|c|c|}
\hline No. & Name & Pretest & Posttest & Gain Score & Category \\
\hline 1. & S1 & 56,25 & 93,75 & 0,86 & High \\
\hline 2. & S2 & 62,50 & 100,00 & 1,00 & High \\
\hline 3. & S3 & 43,75 & 100,00 & 1,00 & High \\
\hline 4. & S4 & 62,50 & 100,00 & 1,00 & High \\
\hline 5. & S5 & 50,00 & 100,00 & 1,00 & High \\
\hline 6. & S6 & 68,75 & 93,75 & 0,80 & High \\
\hline 7. & S7 & 56,25 & 100,00 & 1,00 & High \\
\hline 8. & S8 & 56,25 & 87,50 & 0,71 & High \\
\hline 9. & S9 & 37,50 & 100,00 & 1,00 & High \\
\hline 10. & S10 & 25,00 & 81,25 & 0,75 & High \\
\hline 11. & S11 & 56,25 & 93,75 & 0,86 & High \\
\hline 12. & S12 & 37,50 & 100,00 & 1,00 & High \\
\hline 13. & S13 & 31,25 & 81,25 & 0,73 & High \\
\hline 14. & S14 & 37,50 & 93,75 & 0,90 & High \\
\hline 15. & S15 & 75,00 & 100,00 & 1,00 & High \\
\hline 16. & S16 & 43,75 & 87,50 & 0,78 & High \\
\hline 17. & S17 & 31,25 & 81,25 & 0,73 & High \\
\hline 18. & S18 & 43,75 & 100,00 & 1,00 & High \\
\hline 19. & S19 & 43,75 & 93,75 & 0,89 & High \\
\hline 20. & S20 & 37,50 & 100,00 & 1,00 & High \\
\hline 21. & S21 & 37,50 & 87,50 & 0,80 & High \\
\hline 22. & S22 & 37,50 & 93,75 & 0,90 & High \\
\hline 23. & S23 & 31,25 & 81,25 & 0,73 & High \\
\hline 24. & S24 & 31,25 & 87,50 & 0,82 & High \\
\hline 25. & S25 & 37,50 & 100,00 & 1,00 & High \\
\hline 26. & S26 & 50,00 & 93,75 & 0,88 & High \\
\hline
\end{tabular}

Information: $\mathrm{S}=$ Student

Based on table 8 , it can be seen that the explanation indicator have been successfully trained with all students getting the high category and the average gain score is 0.89 .

The average gain score of students on each indicator critical thinking skills is presented in Figure 4.

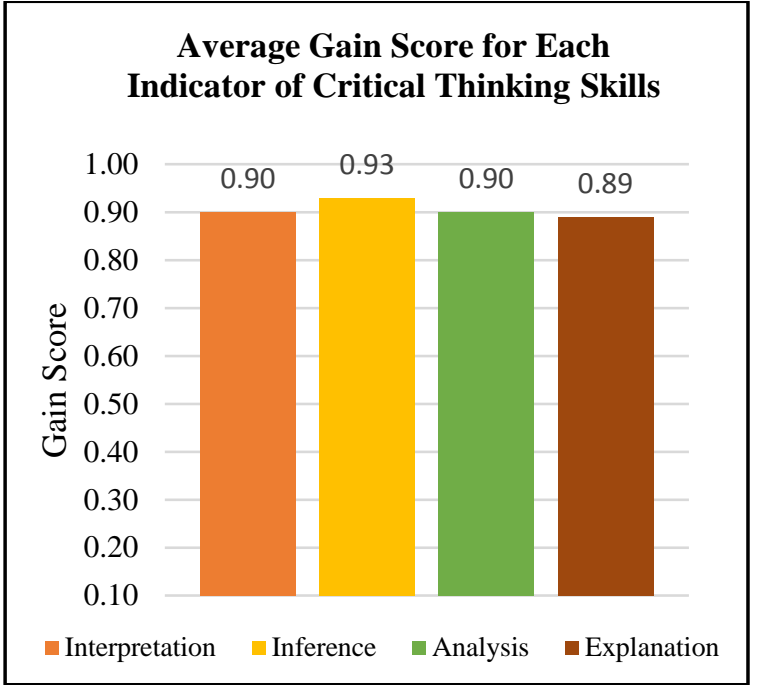

Figure 4. Graph of Average Gain Score for Each Indicator

The four trained indicators show complete results with a high category gain score of $100 \%$ so that students' critical thinking skills have improved very well. It is according to relevant research that states students' critical thinking skills have increased (Ulya \& Nasrudin, 2019).

\section{Students Responses}

Student response data were collected by filling in the Google Form questionnaire link sent to students after learning process ended. The purpose is to find out the response during implementing a guided inquiry learning model with web-assisted courses to improve students' critical thinking skills.

The questionnaire contains 18 positive statements and 2 negative statements. The average percentage of student responses is shown in Figure 5.

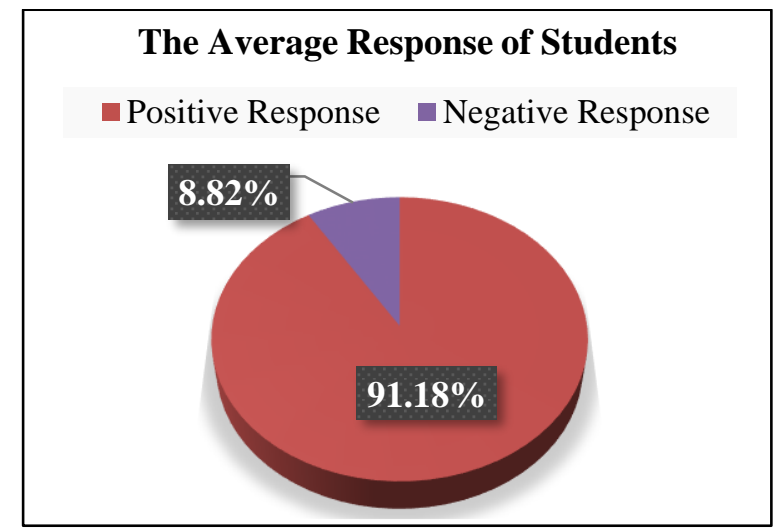

Figure 5. The Graph of Pie Average Percentage of Students

Figure 5 shows that the average percentage of students' positive responses during implementing critical thinking skills through 


\section{Chemistry Education Practice, 4 (3), 2021 - 224}

Indahyana, Nasrudin

guided inquiry learning with web-assisted courses is $91.18 \%$. The criteria are very good because it reaches $\geq 81 \%$.

Students feel happy and not bored during the learning process because even though they are learning online, they can still carry out experimental activities at home by using tools and materials in everyday life. The use of the worksheet has also got a positive response and supports the learning process to become better trained to apply critical thinking skills in their daily lives. The use of YouTube videos as a learning resource get positive response, this is in accordance with the cognitive theory that videos are effective in knowledge construction and memory building (Buzzetto, 2017).

\section{CONCLUSION}

The conclusions of this research are: (1) The implementation of guided inquiry learning model with web-assisted courses to improve critical thinking skills in sub matter factors that affect reaction rate obtained percentage in the first meeting is $98.06 \%$ (very good) and the second meeting is $99.07 \%$ (very good). It means that the learning in two meetings was successful implementation with very good criteria. (2) Students' relevant activities at the first meeting are $98.47 \%$ and the second meeting is $97.84 \%$. The percentage of irrelevant activities is $1.53 \%$ and $2.16 \%$. It means that the activity of students overall is very good and supported the effectiveness of the learning process with relevant activities higher than irrelevant activities. (3) The results of pretest and posttest scores on each critical thinking skill indicator are normally distributed, and there is a difference average which can be seen through the gain score on interpretation indicator is 0.90 (high), inference indicator is 0.93 (high), analysis indicator is 0.90 (high) and the explanation indicator is 0.89 (high). It means that the critical thinking skills students have been successfully trained with increasing gain score in high category $100 \%$. (4) Guided inquiry with webassisted courses to improve students' critical thinking skills get positive response, the results is $91.18 \%$ which is a very good criterion because it has reached $\geq 81 \%$.

\section{REFERENCES}

Arends, R. I. (2012). Learning to Teach Ninth Edition. New York: The McGraw-Hill Companies.

Auliya, N., Yonata, B., \& Ismono. (2020).
Guided Inquiry Implementation to Improve Critical Thinking Skills in Sub Matter Factors that Affect Reaction Rate in SMAN 2 Bangkalan. UNESA Journal of Chemical Education, 9(01), 148-157.

Buzzetto, N. (2017). Student Attitudes Towards the Integration of YouTube in Online, Hybrid, and Web-Assisted Courses: an Examination of the Impact of Course Modality on Perception. MERLOT Journal of Online Learning and Teaching, 11(1), 55-73.

Cahyani, N. I., \& Azizah, U. (2019). Implementation of Guided Inquiry Learning Model to Train Critical Thinking Skills on Reaction Rate Topic Subject in XI SMA Class. UNESA Journal of Chemistry Education, 8(3), 320-326.

Chang, R., \& Overby, J. (2019). Chemistry (13th ed.). New York: McGraw-Hill Education.

Direktorat Pembinaan SMA. (2017). Implementasi Pengembangan Kecakapan Abad 21 dalam Perencanaan Pelaksanaan Pembelajaran (RPP). Jakarta: Kemendikbud.

Facione, P. A. (2015). Critical Thinking: What It Is and Why It Counts. Hermosa Beach: Measured Reasons LLC.

Fadilah, R. T. N., Suyono, \& Mitarlis. (2019). Reaction Rate Materials Learning with Nested Curricular Arrangement Assisted by Web Enhanced Course to Improve Critical Thinking Skills and Student's Learning Outcome. Unesa Journal of Chemical Education, 8(2), 77-84.

Febriani, D. R., \& Ismono. (2020). Implementation of Guided Inquiry Learning Model to Train Critical Thinking Skills on Reaction Rate Class XI. UNESA Journal of Chemical Education, 9(2), 187-192.

Firdausichuuriyah, C., \& Nasrudin, H. (2017). Implementation of Guided Inquiry to Increase Student Critical Thinking Skill on Electrolyte and Non Electrolyte Solution Materials in X Grade of SMAN 4 Sidoarjo. UNESA Journal of Chemical Education, 6(2), 184-189.

Hidayat, F. A. (2017). Pengaruh Pendekatan Inkuiri Terbimbing Dipadu dengan Diagram Alir Terhadap Tingkat Pemahaman dan Hasil Belajar Siswa Kelas XI IPA SMA Muhammadiyah Jayapura pada Materi Laju Reaksi. Jurnal Ilmu Pendidikan Indonesia, 5(1), 35-42. 
Kefalis, C., \& Drigas, A. (2019). Web Based and Online Applications in STEM Education. International Journal of Engineering Pedagogy (IJEP), 9(4),76-85.

Kemendikbud. (2016a). Permendikbud Nomor 20 Tahun 2016 Tentang Standar Kompetensi Lulusan Pendidikan Dasar dan Menengah. Jakarta: Kemendikbud.

Kemendikbud. (2016b). Permendikbud Nomor 22 Tahun 2016 Tentang Standar Proses Pendidikan Dasar dan Menengah. Jakarta: Kemendikbud.

Kemendikbud. (2018a). Permendikbud Nomor 36 Tahun 2018 Tentang Perubahan Atas Permendikbud nomor 59 Tahun 2014 Tentang Kurikulum 2013 SMA/MA. Jakarta: Kemdikbud.

Kemendikbud. (2018b). Permendikbud Nomor 37 Tahun 2018 Tentang Perubahan Atas Permendikbud Nomor 24 Tahun 2016 Tentang Kompetensi Inti dan Kompetensi Dasar Pelajaran pada Kurikulum 2013 pada Pendidikan Dasar dan Pendidikan Menengah. Jakarta: Kemendikbud.

Kemendikbud. (2020). Surat Edaran Kemendikbud Nomor 4 Tahun 2020 Tentang Pelaksanaan Kebijakan Pendidikan dalam Masa Darurat Penyebaran Coronavirus Disease (COVID19). Jakarta: Kemendikbud.

Kepala Badan Penelitian dan Pengembangan dan Perbukuan. (2020). Kompetensi Inti dan Kompetensi Dasar Pelajaran pada Kurikulum 2013 pada Pendidikan Anak Usia Dini, Pendidikan Dasar, dan Pendidikan Menengah Berbentuk Sekolah Menengah Atas untuk Kondisi Khusus. Jakarta: Kemendikbud.

Matondang, S. E. (2017). Pengaruh Media Web pada Pembelajaran Inkuiri Terbimbing Dikombinasikan dengan Lesson Study Terhadap Berpikir Kreatif dan Hasil Belajar Siswa pada Materi Laju Reaksi. Universitas Negeri Medan.

Mukmainah, S. A., \& Yonata, B. (2020). Implementation of Guided Inquiry Learning to Increase Student's Critical Thinking Skill in Material Reaction Rates at SMAN 1 Rengel. UNESA Journal of Chemical Education, 9(1), 133-139.

Munandar, A., \& Amiruddin. (2020). Analisis Penerapan Kurikulum 2013 dalam Meningkatkan Kualitas Pembelajaran Kimia SMA NEGERI 3 Kota Bima. Jurnal Redoks : Jurnal Pendidikan Kimia dan Ilmu
Kimia, 3(2), 1-7.

Plessis, E.C.DU. (2017). The Voice of Student Teachers on E-Learning Initiatives in a Distance Education Community of Practice. Journal for New Generation Science, 15(01), 260-277.

Prayogi, R. D., \& Estetika, R. (2019). Kecakapan Abad 21: Kompetensi Digital Pendidik Masa Depan. Jurnal Manajemen Pendidikan, 14(2), 144-151.

Riduwan. (2015). Skala Pengukuran VariabelVariabel Penelitian. Bandung: Alfabeta.

Titari, I., \& Nasrudin, H. (2017). The Learning Feasibility Strategy Through Cognitive Conflict for Reduction Student's Misconception Class XI SMA Negeri 1 Kertosono in Reaction Rates. UNESA Journal of Chemical Education, 6(2),144149.

Ulya, L. T., \& Nasrudin, H. (2019). Implementation of Guided Inquiry Learning to Train Critical Thinking Skills of Students in the Material Reaction Rates of MAN 1 Tuban XI CLASS. Unesa Journal of Chemical Education, 8(3), 327-331. 